OPEN

SUBJECT AREAS:

SOLAR ENERGY AND

PHOTOVOLTAIC

TECHNOLOGY

SOLAR CELLS

Received

17 September 2014

Accepted

15 December 2014

Published

16 January 2015

Correspondence and requests for materials should be addressed to

T.R. (t.riedl@uniwuppertal.de)

\section{Plasmonically sensitized metal-oxide electron extraction layers for organic solar cells}

\author{
S. Trost, T. Becker, K. Zilberberg, A. Behrendt, A. Polywka, R. Heiderhoff, P. Görrn \& T. Riedl
}

Institute of Electronic Devices, University of Wuppertal, Rainer-Gruenter-Str. 21, 42119 Wuppertal, Germany.

$\mathrm{ZnO}$ and $\mathrm{TiO}_{\mathrm{x}}$ are commonly used as electron extraction layers (EELs) in organic solar cells (OSCs). A general phenomenon of OSCs incorporating these metal-oxides is the requirement to illuminate the devices with UV light in order to improve device characteristics. This may cause severe problems if UV to VIS down-conversion is applied or if the UV spectral range $(\lambda<400 \mathrm{~nm})$ is blocked to achieve an improved device lifetime. In this work, silver nanoparticles (AgNP) are used to plasmonically sensitize metal-oxide based EELs in the vicinity $(1-20 \mathrm{~nm})$ of the metal-oxide/organic interface. We evidence that plasmonically sensitized metal-oxide layers facilitate electron extraction and afford well-behaved highly efficient OSCs, even without the typical requirement of UV exposure. It is shown that in the plasmonically sensitized metal-oxides the illumination with visible light lowers the WF due to desorption of previously ionosorbed oxygen, in analogy to the process found in neat metal oxides upon UV exposure, only. As underlying mechanism the transfer of hot holes from the metal to the oxide upon illumination with $h v<E_{\mathrm{g}}$ is verified. The general applicability of this concept to most common metal-oxides (e.g. $\mathrm{TiO}_{\mathrm{x}}$ and $\mathrm{ZnO}$ ) in combination with different photoactive organic materials is demonstrated.

ubstantial progress in the field of organic solar cells (OSCs) has pushed the device efficiency close to a level of $12 \%{ }^{1}$. Aside from improvements in the design and synthesis of active materials, interface engineering has emerged as a key to increased efficiency and stability ${ }^{2-9}$. For facilitated charge extraction, the interface between the electrodes and the active organic layers is modified by particular treatments, or dedicated interlayers are chosen to match the electronic levels of the electrodes with the transport levels of the organic materials.

In numerous reports, it has been verified that high work-function transition metal oxides ${ }^{10}$, like $\mathrm{MoO}_{\mathrm{x}}{ }^{11,12}$ or $\mathrm{VO}_{\mathrm{x}}{ }^{13,14}$ as interlayers between the organic layer and the anode afford efficient hole extraction in OSCs. At the same time they substantially improve cell stability compared to commonly applied PEDOT:PSS based interlayers.

On the cathode side, interlayers such as titania $\left(\mathrm{TiO}_{\mathrm{x}}\right)^{15,16}$, tin oxide $\left(\mathrm{SnO}_{\mathrm{x}}\right)^{17}$ and zinc oxide $(\mathrm{ZnO})^{18-21}$ have been used to improve electron extraction. Several studies have reported that OSCs incorporating these metaloxide electron extraction layers have to be exposed to UV light with photon energies larger than the band-gap of the respective metal-oxide $\left(h v>E_{\mathrm{g}}\right)$ in order to improve device characteristics ${ }^{16,22-27}$. Without $\mathrm{UV}$ illumination, poor, s-shaped $I / V$ characteristics with a low fill-factor $(F F)$ and overall low power conversion efficiency $(P C E)$ are found. This phenomenon appears to be of general character and is encountered for a large variety of preparation techniques of the metal-oxide layer, e.g. sol-gel coating, atomic layer deposition (ALD), nanoparticle films etc., and regardless of whether single junction devices or multi stacked cells are studied ${ }^{26,27}$. Schmidt et al. have presented evidence of induced oxygen desorption from the $\mathrm{TiO}_{\mathrm{x}}$ surface upon UV illumination and a concomitant lowering of the $\mathrm{TiO}_{\mathrm{x}}$ work function ${ }^{16}$. This effect has been shown to be reversible by re-exposure of the $\mathrm{TiO}_{\mathrm{x}}$ to oxygen. Similar effects have been reported for $\mathrm{ZnO}^{28}$.

Very recently, we were able to show that the origin of poor OSC characteristics without UV exposure can be attributed to an electron extraction barrier at the metal-oxide/organic interface ${ }^{29}$. Unfortunately, to avoid UV induced degradation, many active organic donor materials must be protected from the UV range of the AM1.5 spectrum. Therefore UV blocking filters will have to be used in order to achieve reasonable device lifetimes ${ }^{30-33}$. This would imply that OSCs with interlayers of $\mathrm{TiO}_{\mathrm{x}}$ or $\mathrm{ZnO}$ that require $\mathrm{UV}$ exposure would remain inefficient.

In several recent reports, doped metal-oxide electron extraction interlayers, e.g. $\mathrm{Al}_{\mathrm{ZnO}} \mathrm{Zn}^{29,34,35}$ have been shown to alleviate the need for UV exposure. A severe drawback of solution processed doped metal-oxide layers is the 
typical requirement for elevated processing temperatures $\left(>140^{\circ} \mathrm{C}\right)$, which may limit the choice of substrates and increase the overall manufacturing costs ${ }^{35,36}$.

In this work, we demonstrate that the necessity of UV illumination in $\mathrm{ZnO}$ and $\mathrm{TiO}_{\mathrm{x}}$ based electron extraction layers can be overcome by metal nanoparticles embedded in the metal-oxides in the vicinity of the metal-oxide/organic interface (Figure 1). As we will show, in contrast to devices based on neat $\mathrm{TiO}_{\mathrm{x}}$ and $\mathrm{ZnO}$, the devices with these "plasmonically sensitized electron extraction layers" show well-behaved solar cell characteristics with a high FF and high PCE even without the UV spectral range of the AM1.5 solar spectrum (Figure 1b). The approach to plasmonically sensitize metal-oxides, like $\mathrm{TiO}_{\mathrm{x}}$ and $\mathrm{ZnO}$, with $\mathrm{Au}$ or Ag nanoparticles has recently been used to extend the spectral activity of catalysts, photo-detectors, or photosynthetic devices from the UV into the visible spectral range ${ }^{37-40}$. Aside from a direct transfer of plasmonically excited hot charge carriers from the metal to the semiconductor, a plasmonic resonant energy transfer from metal nanoparticles to a semiconductor may occur ${ }^{41,42}$. As of yet, work to exploit these concepts for improved charge extraction interlayers in OSCs is limited. Choy and coworkers have reported enhanced OSC characteristics upon doping the volume of $\mathrm{TiO}_{\mathrm{x}}$ layers with gold nanoparticles ${ }^{43,44}$. However, the working mechanism of these metal nanoparticles in a metal-oxide charge extraction layer is not clear. Improvements have either been explained by a plasmon-induced electron transfer from the metal nanoparticles to the metal-oxide or by charge accumulation of photo-generated charges transferred from the metaloxide matrix to the metal nanoparticles with negligible contribution of plasmonic effects ${ }^{43,44}$

We clearly evidence that the plasmonic sensitization of $\mathrm{TiO}_{\mathrm{x}}$ or $\mathrm{ZnO}$ with silver nanoparticles (AgNPs) leads to a plasmon resonance in the visible spectral region. As a result, illumination in the subbandgap spectral region of the metal-oxide results in a significant lowering of the work-function (WF), which in neat metal-oxide layers is only possible by above band-gap excitation $\left(h v>E_{\mathrm{g}}\right)$ using UV light. For the application as cathode interlayers in OSCs we show, that efficient electron extraction from OSCs based on various active organic materials, e.g. P3HT:PC ${ }_{60} \mathrm{BM}$ and PCDTBT:PC ${ }_{70} \mathrm{BM}$, is achieved even without UV illumination. Analysis of a model system where we vary the thickness of the metal-oxide cap on top of the AgNPs with nm-precision allows us to unravel the working mechanism in the plasmonically sensitized metal-oxide electron extraction layers. Our results are expected to be of general relevance for organic solar cells and other applications where plasmonic sensitization of metal oxides is applied.

\section{Results and Discussion}

For the realization of plasmonically sensitized electron extraction layers, a thin layer of silver (typically $0.5-0.6 \mathrm{~nm}$ of equivalent mass thickness) is deposited on top of a $35 \mathrm{~nm}$ thick $\mathrm{TiO}_{\mathrm{x}}$ or $\mathrm{ZnO}$ layer (Figure 1a). As expected and visualized by scanning electron microscopy (SEM) (Figure 2a) the evaporated silver forms nanoparticles rather than a continuous thin film. Most AgNP have a diameter $<$ $15 \mathrm{~nm}$ while some larger clusters (up to $60 \mathrm{~nm}$ ) can be found as well (Figure S1c). Further statistical analysis of the size and areal coverage of the AgNPs can be found in the supporting information. We have verified the amount of deposited silver independently by Rutherford backscattering and a mass equivalent of $0.58-0.68 \mathrm{~nm}$ has been found, in excellent agreement with the nominal thickness of Ag for the sample of $0.6 \mathrm{~nm}$ according to quartz crystal monitoring. The AgNPs are then conformally capped by a $\mathrm{TiO}_{\mathrm{x}}$ or $\mathrm{ZnO}$ layer with a thickness $d=1-20 \mathrm{~nm}$ using atomic layer deposition (ALD), denoted as $\mathrm{TiO}_{\mathrm{x}} / \mathrm{AgNP}_{\mathrm{TiO}}(d \mathrm{~nm})$ or $\mathrm{ZnO} / \mathrm{AgNP} / \mathrm{ZnO}(d \mathrm{~nm})$ in the course of the manuscript. Figure $2 b$ shows the scanning electron microscopy (SEM) image of $\mathrm{a} \mathrm{TiO}_{\mathrm{x}} / \mathrm{AgNP}_{\mathrm{TiO}}(3 \mathrm{~nm})$ structure taken at about the same sample position as before the deposition of the $3 \mathrm{~nm} \mathrm{TiO}_{\mathrm{x}}$ cap (Figure 2a). As can be clearly seen, due to the conformal coating in the ALD process the shape of the AgNPs appears virtually unchanged after the deposition of the $\mathrm{TiO}_{\mathrm{x}}$ layer on top.

We deliberately chose to use vacuum deposition with its high level of control for the preparation of the plasmonically sensitized electron extraction layers. However, we want to mention, that $\mathrm{ZnO}, \mathrm{TiO}_{\mathrm{x}}$ and even AgNP can be as well prepared by solution techniques ${ }^{36}$, rendering our results of general relevance even for solution processed applications. We have previously shown that sol-gel and ALD prepared metal-oxide layers behave very similar as electron extraction layer in $\mathrm{OSCs}^{29}$.

Regarding their optical properties, the AgNP sensitized $\mathrm{TiO}_{x}$ layers show a pronounced spectral signature in the sub-bandgap region of the metal-oxide (Figure 3). Instead of the sometimes ambiguous use of "absorption", we decided to use $\left(1-\mathrm{T}_{\perp}-\mathrm{R}_{\perp}\right)$, instead. Here, $\mathrm{T}_{\perp}$ and $\mathrm{R}_{\perp}$ are the transmission and reflection measured perpendicular to the sample surface ("specular"). In perfectly planar thin film stacks light neither reflected nor transmitted can be attributed to absorption within the stack. On the other hand, with silver nanoparticles involved light missing in specular direction may also be scattered diffusively (Figure S2b). Hence, in the spectral region of the plasmon resonance a significant part of $\left(1-\mathrm{T}_{\perp}-\mathrm{R}_{\perp}\right)$ can be attributed to scattering ${ }^{45}$. Thus, for a solar cell, the spectral signature found in the plasmonically sensitized samples does not a-
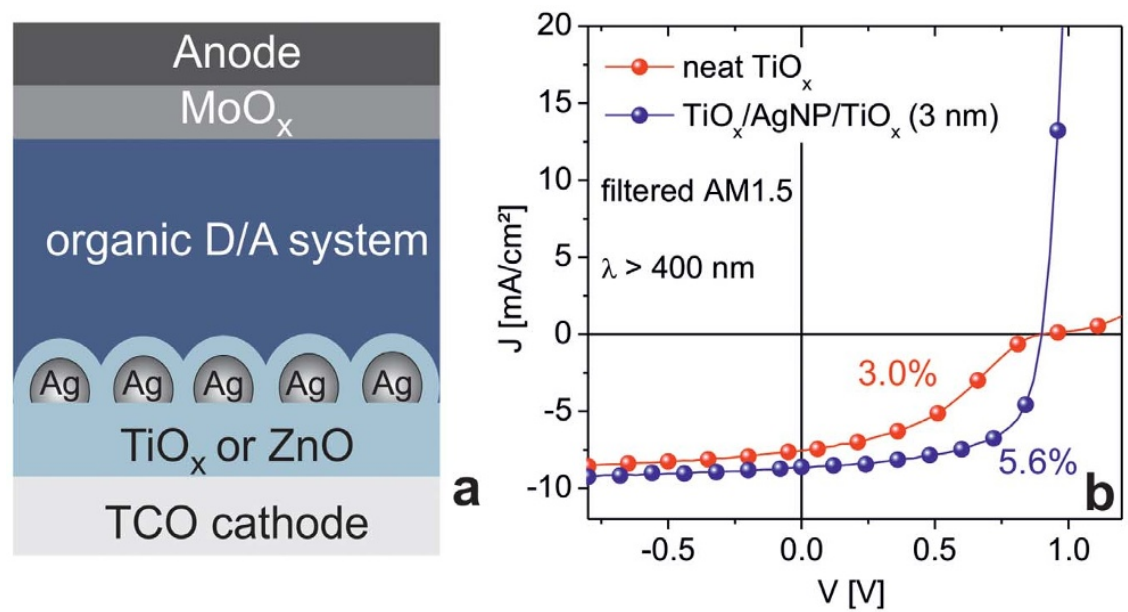

Figure 1 Layer sequence of inverted OSCs with a plasmonically sensitized cathode interlayer (a), and $J / V$ characteristics of a corresponding PCDTBT/ $\mathrm{PC}_{70} \mathrm{BM}$ based OSC under AM1.5 illumination with UV blocking filter $(\lambda>400 \mathrm{~nm})(\mathrm{b})$. The characteristics of an $\mathrm{OSC}_{\text {with a neat TiO }}$ interlayer (w/o AgNP) are shown as a reference. For characteristics under full AM1.5 illumination (with UV range) see supporting information (Table S1). 

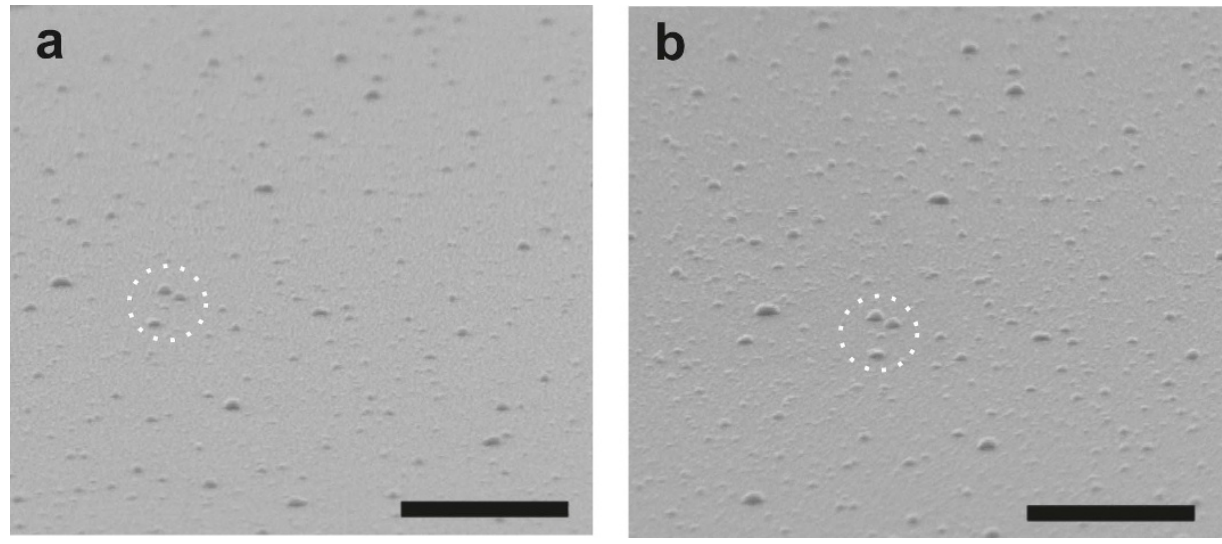

Figure $2 \mid$ SEM images of a thin $(0.6 \mathrm{~nm})$ silver layer, thermally evaporated onto a $\mathrm{TiO}_{\mathrm{x}}$ surface, (a) before, and (b) after coating with an additional $3 \mathrm{~nm}$ thick $\mathrm{TiO}_{\mathrm{x}}$ cap. The scale bars are $500 \mathrm{~nm}$. A characteristic feature is marked by a circle to allow for visual registration of the two slightly offset figures.

priori imply attenuation of the incident solar intensity and in fact no drop in $J_{\mathrm{sc}}$ is found in the corresponding OSCs (see e.g. Figure $1 \mathrm{~b}$ and Table S1). The spectral difference of the external quantum efficiency (EQE) of an OSC based on neat $\mathrm{TiO}_{\mathrm{x}}$ and a plasmonically sensitized $\mathrm{TiO}_{\mathrm{x}}$ layer, respectively, is shown in the supporting information (Figure S3). The EQE of the OSCs with plasmonically sensitized $\mathrm{TiO}_{\mathrm{x}}$ layer is somewhat higher for $\lambda>500 \mathrm{~nm}$. This may be attributed to plasmonic scattering of the incident light, accounting for improved in-coupling. This is in agreement with the scattering spectra showing an onset at $500 \mathrm{~nm}$ (Figure S2b). As a result of the EQE
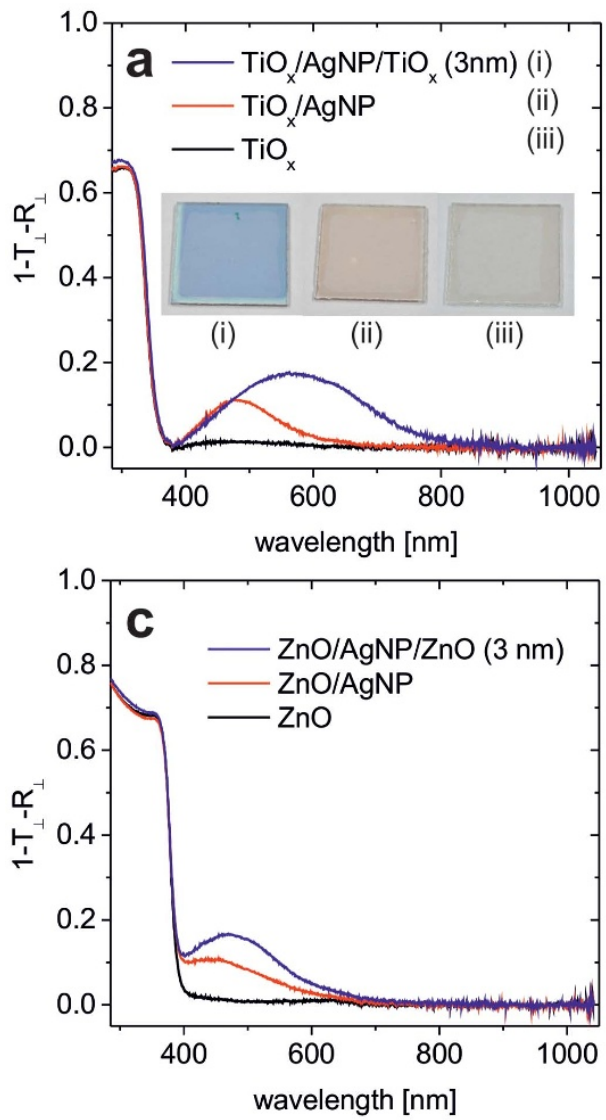

data, a difference of $J_{\mathrm{sc}}$ for the two cells of about $0.5 \mathrm{~mA} / \mathrm{cm}^{2}$ is derived. This is in agreement with the characteristics given in Table S1.

Note, the plasmonic feature in the samples with capped AgNPs $\left(\mathrm{TiO}_{\mathrm{x}} / \mathrm{AgNP} / \mathrm{TiO}_{\mathrm{x}}(3 \mathrm{~nm})\right)$ is substantially red-shifted $\left(\lambda_{p}=\right.$ $570 \mathrm{~nm}$ ) compared to that found in the non-capped $\mathrm{TiO}_{\mathrm{x}} / \mathrm{AgNP}$ sample $\left(\lambda_{p}=480 \mathrm{~nm}\right)$. The inset of Figure 3a shows photographs of the respective layers deposited on glass. The different colour appearance of the capped and non-capped samples is particularly striking. According to the theory of plasmon resonance in small
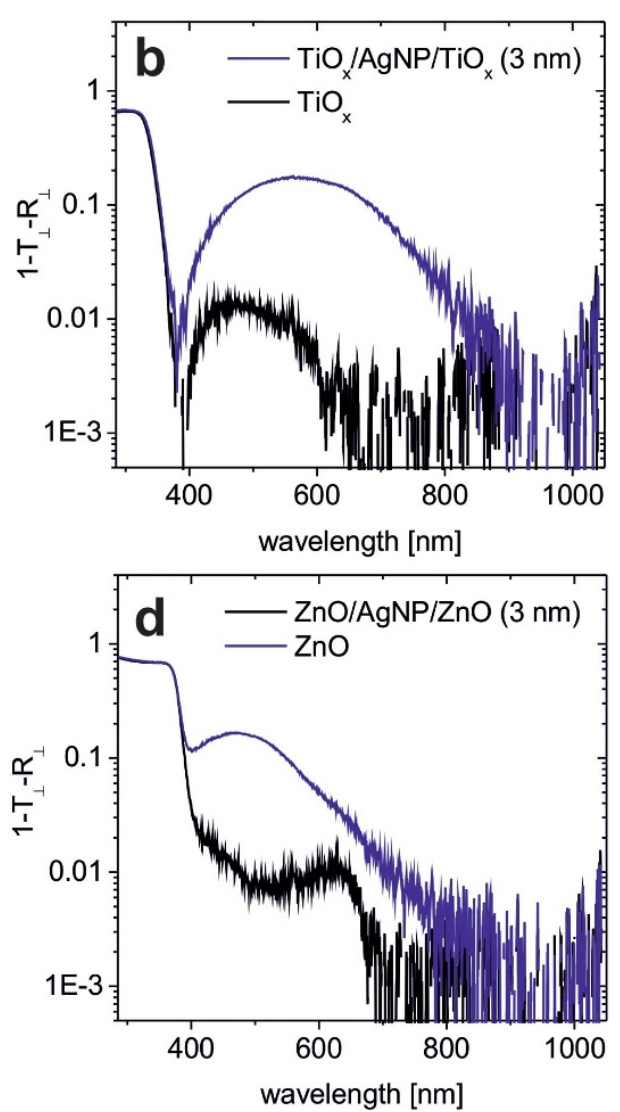

Figure 3 Optical spectra of $\left(1-\mathrm{T}_{\perp}-\mathrm{R}_{\perp}\right)$ for $\mathrm{TiO}_{\mathrm{x}}, \mathrm{TiO}_{\mathrm{x}}$ coated with $0.6 \mathrm{~nm}$ of $\mathrm{Ag}$ and $\mathrm{TiO}_{\mathrm{x}} / \mathrm{AgNP} / \mathrm{TiO}_{\mathrm{x}}(3 \mathrm{~nm})$ in linear (a) and logarithmic $(\mathrm{b})$ representation, to allow for a magnified view of the absorption in the sub-bandgap region. Corresponding spectra of the analogous samples based on $\mathrm{ZnO}(\mathrm{c}, \mathrm{d})$. The overall layer thickness is $100 \mathrm{~nm} . \mathrm{T}_{\perp}$ and $\mathrm{R}_{\perp}$ denote the transmission and reflection measured normal to the sample surface (see Methods). 
Table 1 WF of neat and $\mathrm{AgNP}$ modified $\mathrm{TiO}_{\mathrm{x}}$ and $\mathrm{ZnO}$ layers before exposure to light. Changes of the WF after exposure to AM1.5, filtered $(\lambda>550 \mathrm{~nm})$ and after additional exposure to the full AM1.5 solar spectrum (including UV spectral range) succeeding the $\lambda>550 \mathrm{~nm}$ illumination step. The duration of the illumination was $20 \mathrm{~min}$ in each step and took place under ambient conditions $\left(20^{\circ} \mathrm{C}, 60 \% \mathrm{rH}\right)$

\begin{tabular}{lccc} 
& pristine (dark) & after exposure $\lambda>550 \mathrm{~nm}$ & additional exposure full AM1.5 \\
\hline & $\mathrm{WF}[\mathrm{eV}]$ & $\Delta \mathrm{WF}[\mathrm{eV}]$ & $\Delta \mathrm{WF}[\mathrm{eV}]$ \\
$\mathrm{TiO}_{\times}$ & 4.2 & 0 & -0.2 \\
$\mathrm{TiO}_{x} / \mathrm{AgNP}$ & 4.75 & +0.1 & +0.1 \\
$\mathrm{TiO}_{x} / \mathrm{AgNP} / \mathrm{TiO}_{x}(3 \mathrm{~nm})$ & 4.3 & -0.4 & 0 \\
$\mathrm{ZnO}$ & 4.2 & 0 & -0.2 \\
$\mathrm{ZnO} / \mathrm{AgNP}$ & 4.8 & 0 & 0 \\
$\mathrm{ZnO} / \mathrm{AgNP} / \mathrm{ZnO}(3 \mathrm{~nm})$ & 4.4 & -0.4 & -0.1 \\
\hline
\end{tabular}

metallic particles, the resonance wavelength $\lambda_{p}$ for localized particle plasmons is strongly dependent on the refractive index $n$ of the surrounding matrix. As found in our experiments, an increasing redshift of $\lambda_{p}$ is expected with increasing $n^{46}$. Due to the smaller refractive index of $\mathrm{ZnO}$ compared to $\mathrm{TiO}_{\mathrm{x}}$, the plasmon resonance is found at a shorter wavelength $\left(\lambda_{p}=470 \mathrm{~nm}\right.$ for $\mathrm{ZnO}$ vs. $\lambda_{p}=$ $560 \mathrm{~nm}$ for $\mathrm{TiO}_{\mathrm{x}}$ ) (Figure $3 \mathrm{c}$, d). We have determined the refractive index of $\mathrm{TiO}_{\mathrm{x}}$ and $\mathrm{ZnO}$ to 2.55 and 2.02 (@ $450 \mathrm{~nm}$ ), respectively. Theoretically, one would therefore expect a plasmon resonance of $\lambda_{p}$ $=465 \mathrm{~nm}$ or $\lambda_{p}=540 \mathrm{~nm}$ in the $\mathrm{ZnO}$ and $\mathrm{TiO}_{\mathrm{x}}$ case, which are close to the experimentally found $\lambda_{p}$. In a set of samples $\mathrm{TiO}_{\mathrm{x}} / \mathrm{AgNP}_{\mathrm{TiO}}$ $(d \mathrm{~nm})$ we have varied the thickness $d$ between $3-12 \mathrm{~nm}$ and observed a slight red-shift of $\lambda_{p}$ (Figure S2), in agreement with previous reports ${ }^{47}$.

It has to be noted, that the above calculation of $\lambda_{p}$ holds for spherical particles. It is known that the width and spectral position $\left(\lambda_{p}\right)$ of the plasmon resonance of neat and coated AgNPs depends on the particle shape $\mathrm{e}^{45}$. The shape may be affected by details of the preparation conditions and deviate from that of a sphere or semi-sphere $(\text { Figure } 2)^{48}$. For nominally identical samples we therefore encounter variations of $\lambda_{p}$ on the order of a few tens of $\mathrm{nm}$, which however does not affect the general results of our work reported here.

As can be seen in the logarithmic representations of the absorption spectra, there is some defect state absorption present in the subbandgap region of the neat $\mathrm{TiO}_{\mathrm{x}}$ and $\mathrm{ZnO}$ layers. Absorption features in the sub-bandgap region are commonly attributed to oxygen deficiency in nominally un-doped layers of $\mathrm{TiO}_{\mathrm{x}}$ and $\mathrm{ZnO}^{49,50}$. Oxygen vacancies are expected to be present in the metal oxides used in this study, as all layers have been prepared at relatively low temperatures without high- $T$ post-processing in oxidizing ambient. Plasmonic amplification of such a-priori small (defect related) sub-bandgap absorption in metal-oxides has been reported ${ }^{41,42}$. We will discuss the relevance of plasmonically enhanced sub-bandgap absorption on the working mechanism of the metal-oxide in OSCs below.

Illumination of the plasmonically sensitized metal-oxides in the visible spectral range $\left(h v<E_{\mathrm{g}}\right)$ overlapping the plasmonic peak leads to a significant lowering of the surface work-function, e.g. by $0.4 \mathrm{eV}$ for $\mathrm{TiO}_{\mathrm{x}} / \mathrm{AgNP}_{\mathrm{TiO}} \mathrm{x}(3 \mathrm{~nm})$ (Table 1). On the contrary in the neat metal oxide, UV illumination $\left(h v>E_{\mathrm{g}}\right)$ is required to lower the WF in a comparable manner (Table 1). Interestingly, the samples with AgNP on top of $\mathrm{TiO}_{\mathrm{x}}$ but without additional $\mathrm{TiO}_{\mathrm{x}}$ cap show even a slight increase of the WF upon illumination starting from an overall high WF of $4.75 \mathrm{eV}$. In the literature, reports of the WF neat Ag layers range between $4.26-4.74 \mathrm{eV}^{51-53}$. In contrast to our amorphous $\mathrm{TiO}_{\mathrm{x}}$ layers, a high WF of 5.5-5.8 eV has been reported for $\mathrm{TiO}_{2}$ single crystals $^{54}$. In this case, the deposition of AgNPs has been shown to significantly lower the $\mathrm{WF}$ of the $\mathrm{TiO}_{2}{ }^{55}$. In addition to $\mathrm{TiO}_{\mathrm{x}}$, we have also studied plasmonically sensitized $\mathrm{ZnO}$ (Table 1). As in the case of the sensitized $\mathrm{TiO}_{\mathrm{x}}$, a significant lowering of the WF (by $0.4 \mathrm{eV}$ ) upon illumination with visible light can be achieved. In analogy to neat $\mathrm{TiO}_{\mathrm{x}}$, in neat $\mathrm{ZnO}$, the WF only changes upon illumination with UVphotons $\left(h v>E_{\mathrm{g}}\right)$.
The mechanism that leads to the WF lowering in the plasmonically sensitized samples upon sub-bandgap illumination $\left(h v<E_{\mathrm{g}}\right)$ is notably different from that discussed in recent reports, where a lowering of the WF has been observed in $\mathrm{Ag}$ or Au doped $\mathrm{TiO}_{\mathrm{x}}$ upon UV illumination $\left(h v>E_{\mathrm{g}}\right)$. In these articles, it has been argued, that charges that were photo-generated by UV light in the $\mathrm{TiO}_{\mathrm{x}}$ are subsequently transferred to the metal particles, resulting in the observed shifts of the $\mathrm{WF}^{44}$. On the other hand, it is well known that a lowering of the WF can be found upon illumination with photon energies above the semiconductor band-gap $\left(E_{\mathrm{g}}=3.40 \mathrm{eV}\right.$ for $\mathrm{TiO}_{\mathrm{x}}$ and $3.26 \mathrm{eV}$ for $\mathrm{ZnO}$ ) even without the presence of metal particles ${ }^{16,29}$. Photo-induced desorption of oxygen has been accounted for the observed lowering of the WF in metal-oxides upon UV illumination $^{16,22,56-59}$. Thus, in the framework of the above argumentation the inclusion of metal particles would not be required. Our findings are in striking contrast to these previous reports, as the $\mathrm{WF}$ of our $\mathrm{TiO}_{\mathrm{x}} /$ $\mathrm{AgNP} / \mathrm{TiO}_{\mathrm{x}}(3 \mathrm{~nm})$ samples is lowered upon illumination with visible light $(\lambda>550 \mathrm{~nm})$, already.

To shed more light on the origin of our observation, we have to note that after illumination the WF remains low if the samples are kept in vacuum (Figure 4). On the contrary, in oxygen atmosphere the WF increases rapidly and returns to the same value as before illumination. A further exposure with AM1.5 (with filter: $\lambda>$ $550 \mathrm{~nm}$ ) for $1 \mathrm{~h}$ again lowers the WF, demonstrating the full reversibility of the underlying process. These findings lead us to the conclusion that in the plasmonically sensitized samples the illumination with visible light causes a WF lowering due to desorption of previously ionosorbed oxygen $\left(\mathrm{O}_{2}^{-}(\mathrm{ads}\right.$.)), in clear analogy to the process found in neat metal oxides where illumination with UV is required for oxygen desorption. Typically, photo-induced desorption of oxy-

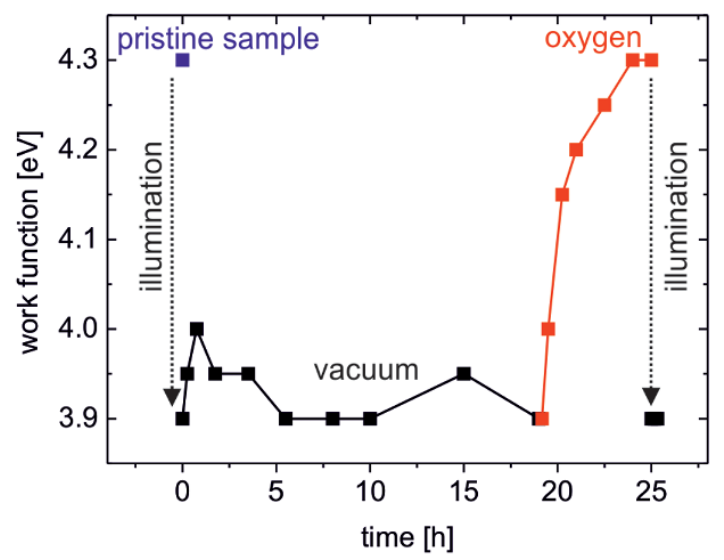

Figure $4 \mid$ Work function of a $\mathrm{TiO}_{\mathrm{x}} / \mathrm{AgNP} / \mathrm{TiO}_{\mathrm{x}}(3 \mathrm{~nm})$ layer after illumination with AM1.5 (with filter: $\lambda>550 \mathrm{~nm}$ ) for $1 \mathrm{~h}$ upon storage in vacuum (pressure: $10^{-6} \mathrm{mbar}$ ) for several hours, subsequent exposure to oxygen atmosphere and repeated illumination with AM1.5 (with filter: $\lambda>550 \mathrm{~nm}$ ) for $1 \mathrm{~h}$. 

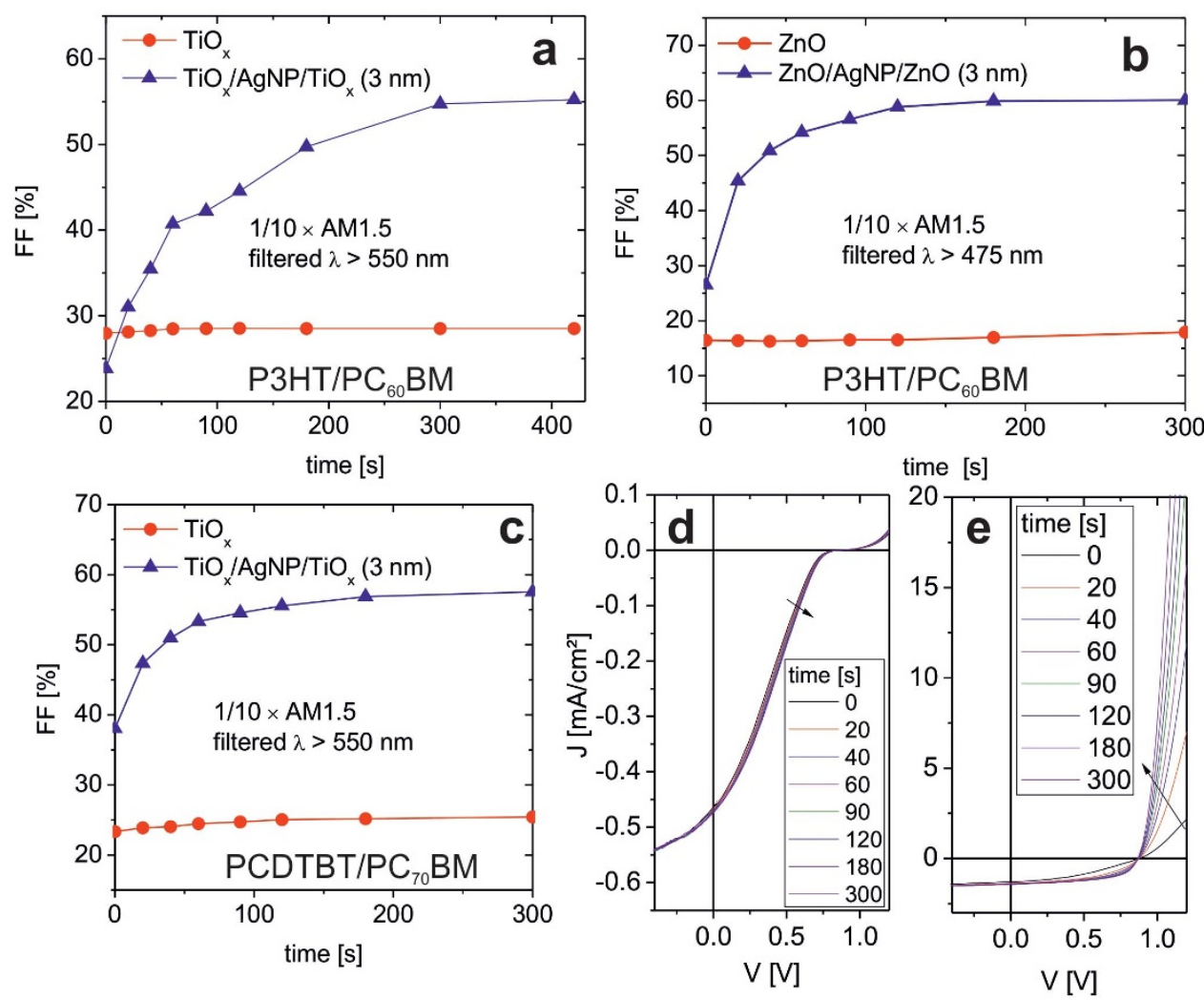

Figure 5 FF vs. time of inverted OSCs based on neat and plasmonically sensitized $\mathrm{TiO}_{\mathrm{x}}(\mathrm{a}, \mathrm{c})$ and $\mathrm{ZnO}$ (b) during illumination with $1 / 10$ of the AM1.5 radiation with UV spectral range blocked (either $\lambda>550 \mathrm{~nm}$ or $\lambda>475 \mathrm{~nm}$ ). Photoactive material is $\mathrm{P} 3 \mathrm{HT}: \mathrm{PC}_{60} \mathrm{BM}$ for $(\mathrm{a}, \mathrm{b})$ and PCDTBT:PC ${ }_{70} B M$ for (c-e) (for details see Methods section). (d) and (e) display the $J / V$ characteristics corresponding to the $F F$ data shown in (c).

gen requires photo-generated holes to neutralize the negatively charged adsorbed oxygen ${ }^{60}: \mathrm{O}_{2}^{-}($ads. $)+h^{+} \rightarrow \mathrm{O}_{2}{ }^{\uparrow}$ As a result, plasmonically excited hot electrons transferred from the AgNPs to the metal-oxide cannot account for this desorption mechanism, rather the transfer of hot holes must be considered ${ }^{61}$.

Aside from a direct transfer of hot charge carriers from the metal to the semiconductor, the plasmonic resonant energy transfer from metal nanoparticles to the metal oxide and its defect-states could be considered to explain the observed lowering of the WF. This mechanism allows for the plasmonic amplification of sub-bandgap absorption in the metal-oxide as seen in Figure 3 a,c. A similar effect has previously been evidenced to account for an efficient generation of electron-hole pairs upon sub-bandgap illumination ${ }^{41,42}$. The hole generated in his process may then promote desorption of oxygen. If the latter mechanism would be responsible for the observed WF lowering and oxygen desorption, we would expect that illumination of the non-sensitized metal-oxide within the spectral region of its sub-bandgap absorption would also cause some shift of the WF. However, this is not observed (see Table 1 and Figure S4).

It is now instructive to study these metal-oxides as electron extraction layers in OSCs. Here, the fill factor $(F F)$ is monitored vs. time during illumination with AM1.5 solar light with UV spectral range blocked (Figure $5 \mathrm{a}-\mathrm{c})$. OSCs with non-sensitized metal oxides $\left(\mathrm{TiO}_{\mathrm{x}}\right.$ or $\mathrm{ZnO}$ ) remain in a state of low $F F<40 \%$ and thus low $P C E$ (with sshaped $I / V$ characteristics as seen exemplary in Figure 1b). This situation does not change even if the illumination intensity is increased by an order of magnitude and is extended to $1 \mathrm{~h}$ duration. It has to be noted, that the AM1.5 solar spectrum delivers an intensity of about $15 \mathrm{~mW} / \mathrm{cm}^{2}$ between 550 and $650 \mathrm{~nm}$. Even if we use a green laser to supply a significantly higher intensity $(\lambda=532 \mathrm{~nm}$, $700 \mathrm{~mW} / \mathrm{cm}^{2}$ ), the $F F$ of non-sensitized samples remains low after $1 \mathrm{~h}$ of continuous illumination. Therefore, the excitation of nonsensitized metal oxides via sub-bandgap defect states does not appear to account for oxygen desorption and the concomitant lowering of the WF. On the contrary, during illumination with a tenfold attenuated AM1.5 solar radiation with UV spectral range blocked, the devices based on plasmonically sensitized electron extraction layers show a continuous improvement of the $F F$ until a saturated state with a high FF and high PCE is reached within less than 5 min (Figure 5 ac). This finding holds for both $\mathrm{TiO}_{\mathrm{x}}$ and $\mathrm{ZnO}$ layers sensitized by AgNPs and applies regardless of whether P3HT:PC ${ }_{60} \mathrm{BM}$ or PCDTBT:PC ${ }_{70} \mathrm{BM}$ is used as photoactive layer. Note, a table with the characteristics of the OSC devices studied here can be found in the supporting information (Table S1).

It is important to note that a control device with no AgNPs but with an additional $3 \mathrm{~nm}$ ALD $\mathrm{TiO}_{\mathrm{x}}$ cap $\left(\mathrm{TiO}_{\mathrm{x}} /\right.$ no $\mathrm{AgNP} / \mathrm{TiO}_{\mathrm{x}}$ $(3 \mathrm{~nm})$ ) did show a similar behaviour as a device with neat $\mathrm{TiO}_{\mathrm{x}}$ (Figure S5). In previous work, it has been found that thin metal-oxide layers deposited by ALD already led to some improvement of device characteristics due to reduced recombination at the electrode/ organic interface ${ }^{62,63}$. However, as the bottom $\mathrm{TiO}_{\mathrm{x}}$ layer in our experiments has been deposited by ALD, the additional deposition of a thin $\mathrm{TiO}_{\mathrm{x}}$ layer on top is not expected to lead to similar improvements.

In view of our results, we conclude that in the plasmonically sensitized metal-oxide electron extraction layers holes are transferred from the metal to the oxide upon illumination with $h v<E_{\mathrm{g}}$. This leads to desorption of ionosorbed oxygen and a concomitant lowering of the WF. A plasmonically mediated transfer of holes from the metal to a semiconductor has been predicted theoretically by Govorov et al., very recently ${ }^{64}$.

Finally, we studied the impact of the variation of the over-layer thickness $d$ in $\mathrm{TiO}_{\mathrm{x}} / \mathrm{AgNP} / \mathrm{TiO}_{\mathrm{x}}(d \mathrm{~nm})$ electron extraction layers. ALD allows us to vary $d$ with a high level of precision. The characteristics of the respective inverted organic solar cells based on PCDTBT:PC ${ }_{70} \mathrm{BM}$ are shown in Figure 6. The cells have been illu- 
Filter: $\lambda>550 \mathrm{~nm}$
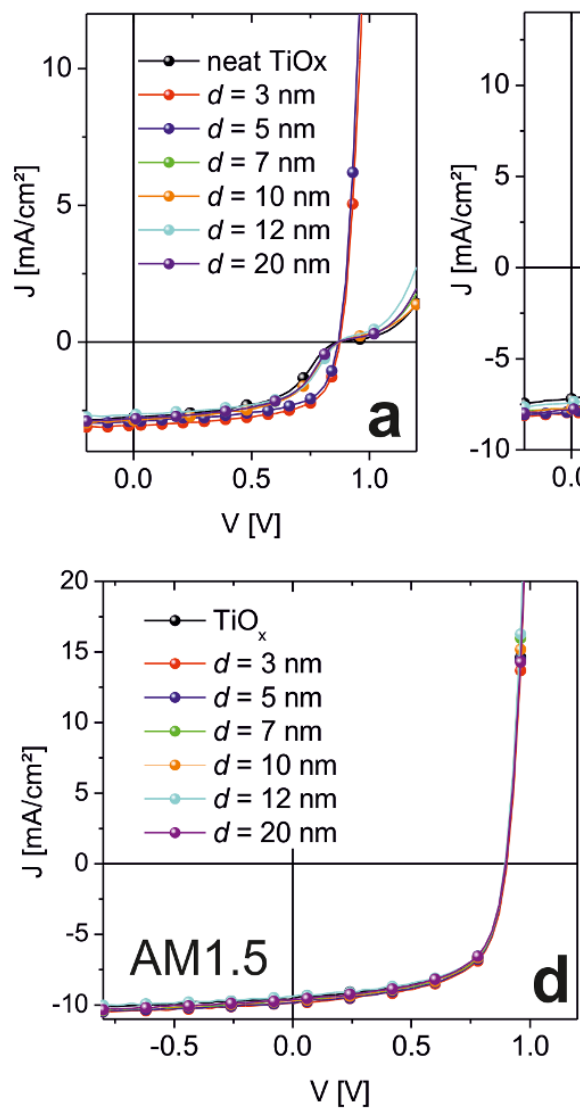

$\lambda>435 \mathrm{~nm}$

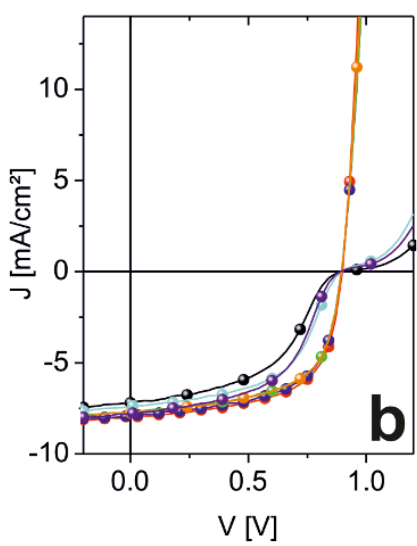

$\lambda>400 \mathrm{~nm}$

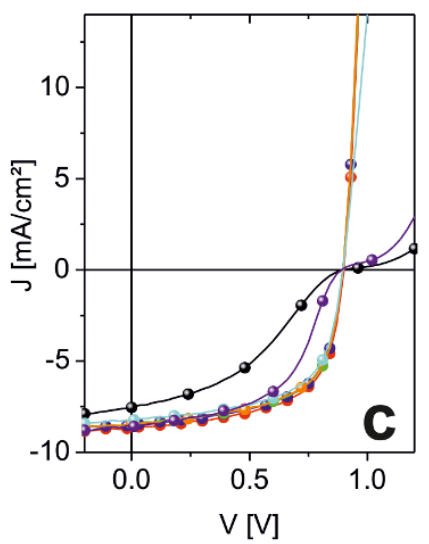

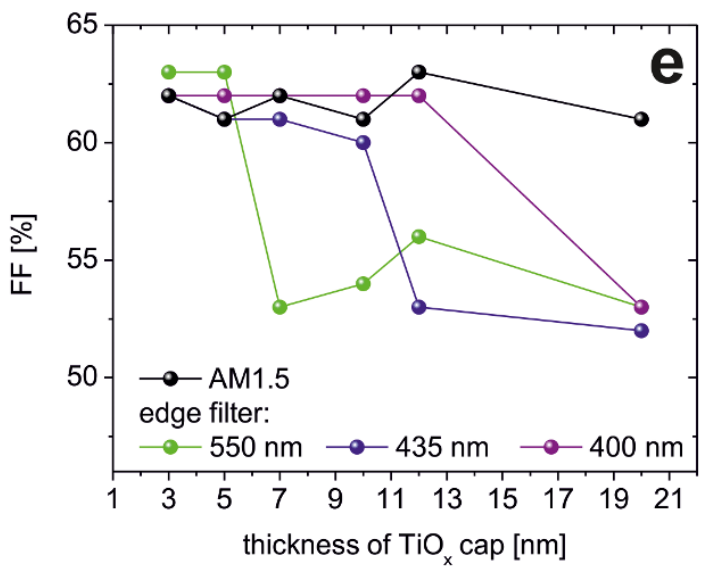

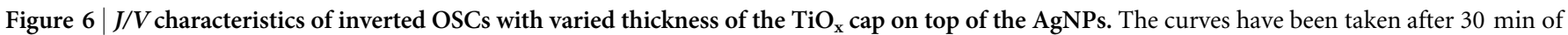
illumination with filtered AM1.5 light using long-pass filters with $\lambda>550 \mathrm{~nm}$ (a), $\lambda>435 \mathrm{~nm}$ (b), and $\lambda>400 \mathrm{~nm}$ (c). J/V characteristics upon unfiltered AM1.5 illumination (d). FF for the devices with different thickness of the $\mathrm{TiO}_{\mathrm{x}}$ cap derived from the $J / V$ characteristics (e).

minated with AM1.5 light filtered with long-pass filters $(\lambda>550 \mathrm{~nm}$ or $\lambda>435 \mathrm{~nm}$ or $\lambda>400 \mathrm{~nm}$ ) for $30 \mathrm{~min}$. In the case of $\lambda>$ $550 \mathrm{~nm}$, only the samples with $d=3 \mathrm{~nm}$ and $5 \mathrm{~nm}$ show wellbehaved, kink-free $J / V$ characteristics. Very interestingly, in the case of thicker $\mathrm{TiO}_{\mathrm{x}}$ over-layers a shorter wavelength is required to remove the s-shape. E.g. while the samples with $d \geq 7 \mathrm{~nm}$ remain s-shaped upon illumination with $\lambda>550 \mathrm{~nm}$, the s-shape disappears for $d=7 \mathrm{~nm}$ and $10 \mathrm{~nm}$ upon illumination with a shorter wavelength $\lambda>435 \mathrm{~nm}$. Finally, illumination with $\lambda>400 \mathrm{~nm}$ leads to well-behaved $J / V$ characteristics also in the case of $d=$ $12 \mathrm{~nm}$. Note, the samples with neat $\mathrm{TiO}_{\mathrm{x}}$ and those with $d=$ $20 \mathrm{~nm}$ remain s-shaped for $\lambda>400 \mathrm{~nm}$. This is also found for $\mathrm{TiO}_{\mathrm{x}} / \mathrm{AgNP}$ with a $\mathrm{TiO}_{\mathrm{x}}$ cap of $1 \mathrm{~nm}$ or less (not shown here). Only upon illumination with full (unfiltered) AM1.5 light, all cells show essentially similar characteristics (Figure $6 \mathrm{~d}$ and Table S1). A summary of all $F F$ of the cells upon different illumination conditions is provided by Figure 6 e. From an application perspective, the cap thickness may vary between $3 \mathrm{~nm}$ and $12 \mathrm{~nm}$ to allow for wellbehaved cell characteristics even in the absence of the UV spectral range. This may partially relax concerns of a limited thickness control and conformality when solution processed EELs are to be used.

The strong spectral dependence with respect to the thickness of the $\mathrm{TiO}_{\mathrm{x}}$ cap sheds light on the working mechanism of the plasmonically sensitized electron extraction layers. It has to be recalled that on the contrary the plasmon resonance spectra for a cap thickness $d$ between $3 \mathrm{~nm}$ and $12 \mathrm{~nm}$ only show a small variation in shape and spectral position $\left(\lambda_{p}\right)$ (Figure S2). It is well known that at the interface of $\mathrm{Ag}$ and $\mathrm{TiO}_{\mathrm{x}}$ a Schottky barrier $\phi_{\mathrm{B}}=E_{A}\left(\mathrm{TiO}_{\mathrm{x}}\right)-\mathrm{WF}(\mathrm{Ag})$ is formed (Figure 7a). Note for our $\mathrm{TiO}_{\mathrm{x}}$ we have previously deter- mined an electron affinity of 4.0-4.1 eV while for Ag a work function of $4.7 \mathrm{eV}$ is found by us and others ${ }^{53}$. According to Wood et al. the WF of small Ag particles $(3-5 \mathrm{~nm})$ is expected to be somewhat increased by $0.2-0.4 \mathrm{eV}$ compared to bulk silver. This leads to an estimate for $\phi_{B}$ in the range of $0.6-1.1 \mathrm{eV}$. The width $w$ of the depletion region depends on $\phi_{\mathrm{B}}$ and the Debye length $L_{\mathrm{D}}=\left(\varepsilon_{\mathrm{r}} \varepsilon_{0} k T / e^{2} N\right)^{1 / 2}$. $\varepsilon_{\mathrm{r}}$ is the relative dielectric permittivity of $\mathrm{TiO}_{\mathrm{x}}$ and $N$ is the charge carrier density. Even though, we were not able to determine the carrier density in our $\mathrm{TiO}_{\mathrm{x}}$ layers using Hall, there are studies on similar ALD grown $\mathrm{TiO}_{\mathrm{x}}$ layers reporting a carrier density on the order of $N=10^{18} \mathrm{~cm}^{-365}$ and an $\varepsilon_{r}$ of about $70^{66}$. Therefore, we can estimate $L_{\mathrm{D}}$ to be on the order of $10 \mathrm{~nm}$. If the thickness $d$ of the $\mathrm{TiO}_{\mathrm{x}}$ cap layer is smaller than $L_{\mathrm{D}}$, the band bending in the semiconductor is almost absent. In this case, the Fermi-level will be located more in the center of the $\mathrm{TiO}_{\mathrm{x}}$ band-gap as compared to bulk- $\mathrm{TiO}_{\mathrm{x}}$ (Figure $7 \mathrm{~b}$ ). $E(d)=E_{F}-E_{V B}(d)$ is a measure for the energy of a photon required to generate a hole that can be transferred into the valence band of the $\mathrm{TiO}_{\mathrm{x}}$ and that may subsequently neutralize an ionosorbed oxygen molecule $\left(\mathrm{O}_{2}^{-}(a d s).\right)$. It is important to note, that the spatial extension of localized surface plasmons (LSP) has been the subject of several studies which have been reviewed by Kedem et al., recently ${ }^{67}$. Ranges in excess of $10 \mathrm{~nm}$ have been reported for noble metal particle $\operatorname{LSPs}^{47,67}$.

With $\phi_{B}=1 \mathrm{eV}$, we would expect excitation with low-energy light $(\lambda>550 \mathrm{~nm})$ to be sufficient for samples with very thin caps $d=3-$ $5 \mathrm{~nm}<L_{D}$ (Figure 7b). This is in agreement with our experimental findings (Figure 6). $E(d)$ is estimated to be roughly $E_{F}-E_{V B}(d=\infty)$ $\phi_{B} \approx 2.1 \mathrm{eV}(\lambda<590 \mathrm{~nm})$. With increasing thickness of the $\mathrm{TiO}_{\mathrm{x}}$, more pronounced band-banding is expected and the photon-energy 
to create a hole that can be transferred to the valence band of the $\mathrm{TiO}_{\mathrm{x}}$ increases concomitantly (Figure 7c). According to the experimental data (Figure 6), for $d=10 \mathrm{~nm}$ illumination with $\lambda<550 \mathrm{~nm}$ (eq. $>$ $2.25 \mathrm{eV}$ ) and for $d=12 \mathrm{~nm}$ illumination with $\lambda<435 \mathrm{~nm}$ (eq. $>$ $2.85 \mathrm{eV}$ ) is found necessary.

Thus, our precise variation of the $\mathrm{TiO}_{\mathrm{x}}$ cap thickness allows us to literally trace the band bending at the $\mathrm{AgNP} / \mathrm{TiO}_{\mathrm{x}}$ hetero-interface. Moreover, the results of this experiment support the conclusion, that the transfer of holes from the metal to the metal-oxide accounts for desorption of chemisorbed oxygen, the lowering of the WF and the improved OSC characteristics. As the AgNP cover only about $6 \%$ of the $\mathrm{TiO}_{\mathrm{x}}$ surface, transferred holes must be able to diffuse to noncovered regions of the $\mathrm{TiO}_{\mathrm{x}}$. Diffusion lengths of minority carriers (holes) in titania have been reported to be on the order of 10 $100 \mathrm{~nm}^{68,69}$

\section{Conclusions}

In summary, we have presented plasmonically sensitized electron extraction layers based on $\mathrm{TiO}_{\mathrm{x}}$ and $\mathrm{ZnO}$. Silver nanoparticles in the immediate vicinity of the metal-oxide/organic interface have been shown to significantly improve electron extraction in inverted organic solar cells even without the need for UV light soaking. We have evidenced that in the plasmonically sensitized metal-oxides the illumination with visible light lowers the WF due to desorption of previously ionosorbed oxygen, in analogy to the process found in neat metal oxide where illumination with UV is required for oxygen desorption. This mechanism is explained by a plasmonically mediated transfer of holes from the metal to the oxide upon illumination with $h v<E_{\mathrm{g}}$. The general applicability of this concept to most common metal-oxides (e.g. $\mathrm{TiO}_{\mathrm{x}}$ and $\mathrm{ZnO}$ ) in combination with different photoactive organic materials (e.g. P3HT:PC ${ }_{60} \mathrm{BM}$ and PCDTBT:PC ${ }_{70} \mathrm{BM}$ ) is demonstrated.
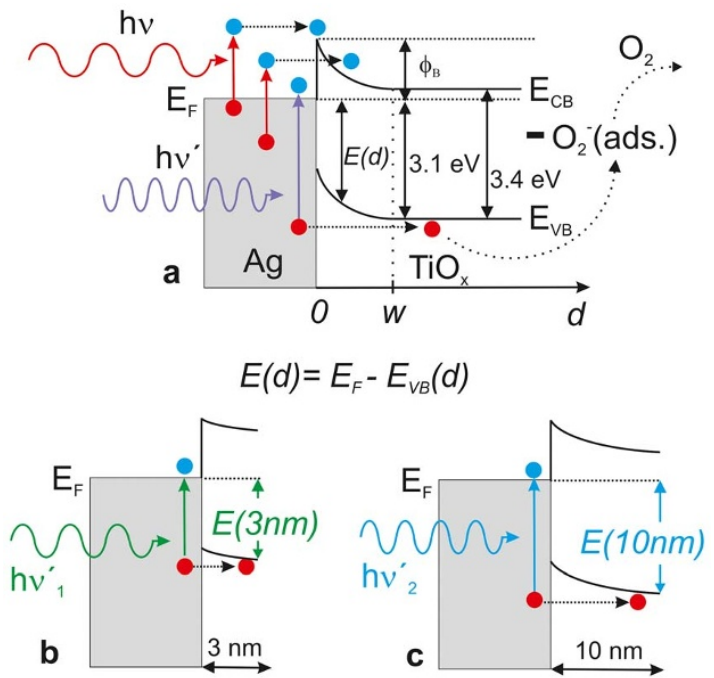

Figure 7 | Schematic of an $\mathrm{Ag} / \mathrm{TiO}_{\mathrm{x}}$ junction (a). The bandgap energy of $\mathrm{TiO}_{\mathrm{x}}$ and the position of the valence band with respect to the Fermi level have been taken from our previous work ${ }^{29}$. Upward band bending at the surface of the $\mathrm{TiO}_{\mathrm{x}}$ due to ionosorbed $\mathrm{O}_{2}^{-}(\mathrm{ads}$.) has been neglected for simplicity. According to work by Göpel et al., the effective surface state energy of $\mathrm{O}_{2}^{-}$(ads.) (relative to the Fermi energy under flat-band conditions) is $-0.7 \mathrm{eV}$ for neat titania surfaces ${ }^{72,73}$. Red vertical arrows show the well-established plasmonic transfer of hot electrons to the $\mathrm{CB}$ of $\mathrm{TiO}_{\mathrm{x}}$. The generation of a hole that can be transferred to the $\mathrm{VB}$ of the $\mathrm{TiO}_{\mathrm{x}}$ requires photons with an energy $h v^{\prime}>E(d)$. Scheme for a very thin cap $(d$ $\left.<L_{D}\right)$, e.g. $3 \mathrm{~nm}(\mathrm{~b})$, and $10 \mathrm{~nm}\left(d \approx L_{D}\right)($ c).

\section{Methods}

Materials synthesis and device preparation. The inverted polymer-fullerene OSCs studied in this work are based on the following layer sequence: glass/ITO/interlayer/ photoactive layer $/ \mathrm{MoO}_{3} / \mathrm{Ag}$ (see Figure 1a) with an active area of $0.03 \mathrm{~cm}^{2} . \mathrm{TiO}_{\mathrm{x}}$, $\mathrm{ZnO}$ were deposited by atomic layer deposition in a Beneq TFS 200 ALD reactor (substrate temperature $80^{\circ} \mathrm{C}$ ). For the preparation of $\mathrm{TiO}_{\mathrm{x}}$, we used

Tetrakis(dimethylamino)titanium and water as precursors. $\mathrm{ZnO}$ was deposited from diethyl zinc and water. Silver has been deposited by thermal evaporation on top of the respective metal-oxide layers. A typical equivalent mass thickness of $0.5-0.6 \mathrm{~nm}$ has been deposited as controlled by quartz crystal monitoring. By equivalent mass thickness we mean the mass of a homogeneous thin film of silver with a thickness of 0.5-0.6 nm. The QCM has been calibrated by depositing thicker Ag layers which are homogeneous and allow for thickness measurement by stylus profiling. The number of Ag atoms per area has independently been determined by Rutherford backscattering.

As polymer:fullerene blend, poly(3-hexylthiophene-2,5-diyl) (P3HT) (supplied by Honeywell Chemicals Seelze) and $\mathrm{PC}_{60} \mathrm{BM}$ (ADS) with a weight ratio of $1: 1$ was spincoated under $\mathrm{N}_{2}$-atmosphere from a chlorobenzene and chloroform (vol. ratio $1: 1$ ) solution $\left(16 \mathrm{mg} \mathrm{m}^{-1}\right.$ ) using a PTFE $0.2 \mu \mathrm{m}$ filter. The layers were subsequently annealed in $\mathrm{N}_{2}$ at $110^{\circ} \mathrm{C}$ for $8 \mathrm{~min}$ resulting in an active layer with thickness of $200 \mathrm{~nm}$. Alternatively, Poly[N-9'-heptadecanyl-2,7-carbazole-alt-5,5-(4',7'-di-2thienyl-2',1',3'-benzothiadiazole)] (PCDTBT) (supplied by PCAS) and PC $_{70} \mathrm{BM}$ (SES Research or Solenne) with a weight ratio of $1: 4$ was dissolved in o-dichlorobenzene $\left(20 \mathrm{mg} \mathrm{ml}^{-1}\right)$ and stirred in $\mathrm{N}_{2}$ atmosphere at $80^{\circ} \mathrm{C}$ for $24 \mathrm{~h}$. The still warm solution $\left(70^{\circ} \mathrm{C}\right)$ was filtered $(5 \mu \mathrm{m}$ PTFE Filter) and spin coated at $1000 \mathrm{rpm}$ for $60 \mathrm{~s}$ with open lid. The resulting layers (thickness $\approx 60 \mathrm{~nm}$ ) were subsequently annealed for $10 \mathrm{~min}$ at $70^{\circ} \mathrm{C}$ on a hotplate in $\mathrm{N}_{2}$ atmosphere.

On the anode side, $\mathrm{MoO}_{3}(15 \mathrm{~nm}), \mathrm{Ag}(100 \mathrm{~nm})$ layers were thermally evaporated in high-vacuum $\left(10^{-7} \mathrm{mbar}\right)$.

Materials and device characterization. The solar cells were characterized in ambient air without encapsulation using a Keithley 2400-C source meter and a solar simulator (300 W Newport, AM1.5G, $100 \mathrm{mWcm}^{-2}$ ). Long-pass filters and reflective grey scale filters were used as indicated in the manuscript.

For determining transmission and reflection spectra a Deuterium Halogen lamp (DH-2000-BAL, OceanOptics) and a spectrometer with a range from $186 \mathrm{~nm}$ to $1041 \mathrm{~nm}$ (USB 2000+XR1-ES) were used. Spectra were either recorded in specular direction or with the detector placed under an angle of $45^{\circ}$ with respect to the surface normal to analyze scattered transmission.

The measurements of the surface potential were done with a McAllister KP6500 Kelvin-Probe (KP) system in ambient air or under controlled atmosphere (vacuum, pure oxygen). Highly ordered pyrolytic graphite with a WF of $4.5 \mathrm{eV}$ was used as reference ${ }^{70,71}$.

The SEM studies were conducted using a Philips XL30S FEG microscope with a field emission cathode.

1. Chen, C.-C. et al. An Efficient Triple-Junction Polymer Solar Cell Having a Power Conversion Efficiency Exceeding 11\%. Adv Mater 26, 5670-5677, doi:10.1002/ adma.201402072 (2014).

2. Po, R., Carbonera, C., Bernardi, A. \& Camaioni, N. The role of buffer layers in polymer solar cells. Energy \& Environmental Science 4, 285-310, doi:10.1039/ c0ee00273a (2011).

3. Yip, H.-L. \& Jen, A. K. Y. Recent advances in solution-processed interfacial materials for efficient and stable polymer solar cells. Energy \& Environmental Science 5, 5994-6011, doi:10.1039/c2ee02806a (2012).

4. Greiner, M. T. et al. Universal energy-level alignment of molecules on metal oxides. Nat Mater 11, 76-81, doi:10.1038/nmat3159 (2012).

5. Zhou, Y. et al. A Universal Method to Produce Low-Work Function Electrodes for Organic Electronics. Science 336, 327-332, doi:10.1126/science.1218829 (2012).

6. He, Z. et al. Enhanced power-conversion efficiency in polymer solar cells using an inverted device structure. Nat Photon 6, 591-595, doi:10.1038/nphoton.2012.190 (2012).

7. Ratcliff, E. L., Zacher, B. \& Armstrong, N. R. Selective Interlayers and Contacts in Organic Photovoltaic Cells. The Journal of Physical Chemistry Letters 2, 1337-1350, doi:10.1021/jz2002259 (2011).

8. Chen, S., Manders, J. R., Tsang, S. W. \& So, F. Metal oxides for interface engineering in polymer solar cells. J Mater Chem 22, 24202-24212, doi:10.1039/ C2jm33838f (2012).

9. Steim, R., Kogler, F. R. \& Brabec, C. J. Interface materials for organic solar cells. J Mater Chem 20, 2499-2512, doi:10.1039/b921624c (2010).

10. Meyer, J. et al. Transition Metal Oxides for Organic Electronics: Energetics, Device Physics and Applications. Adv Mater 24, 5408-5427, doi:10.1002/ adma.201201630 (2012).

11. Hammond, S. R. et al. Low-temperature, solution-processed molybdenum oxide hole-collection layer for organic photovoltaics. J Mater Chem 22, 3249-3254 (2012).

12. Zilberberg, K., Gharbi, H., Behrendt, A., Trost, S. \& Riedl, T. Low-Temperature, Solution-Processed MoOx for Efficient and Stable Organic Solar Cells. Acs Appl Mater Inter 4, 1164-1168, doi:10.1021/am201825t (2012). 
13. Zilberberg, K., Trost, S., Schmidt, H. \& Riedl, T. Solution Processed Vanadium Pentoxide as Charge Extraction Layer for Organic Solar Cells. Adv Energy Mater 1, 377-381, doi:10.1002/aenm.201100076 (2011).

14. Zilberberg, K. et al. Inverted Organic Solar Cells with Sol-Gel Processed High Work-Function Vanadium Oxide Hole-Extraction Layers. Adv Funct Mater 21, 4776-4783, doi: 10.1002/adfm.201101402 (2011).

15. Waldauf, C. et al. Highly efficient inverted organic photovoltaics using solution based titanium oxide as electron selective contact. Applied Physics Letters 89, 233517 (2006).

16. Schmidt, H. et al. Transient characteristics of inverted polymer solar cells using titaniumoxide interlayers. Appl Phys Lett 96, 243305 (2010).

17. Trost, S., Zilberberg, K., Behrendt, A. \& Riedl, T. Room-temperature solution processed $\mathrm{SnOx}$ as an electron extraction layer for inverted organic solar cells with superior thermal stability. J Mater Chem 22, 16224-16229 (2012).

18. White, M. S., Olson, D. C., Shaheen, S. E., Kopidakis, N. \& Ginley, D. S. Inverted bulk-heterojunction organic photovoltaic device using a solution-derived $\mathrm{ZnO}$ underlayer. Appl Phys Lett 89, 143517 (2006).

19. Sun, Y. M., Seo, J. H., Takacs, C. J., Seifter, J. \& Heeger, A. J. Inverted Polymer Solar Cells Integrated with a Low-Temperature-Annealed Sol-Gel-Derived ZnO Film as an Electron Transport Layer. Adv Mater 23, 1679-+, doi:DOI 10.1002/ adma.201004301 (2011).

20. Sondergaard, R., Helgesen, M., Jorgensen, M. \& Krebs, F. C. Fabrication of Polymer Solar Cells Using Aqueous Processing for All Layers Including the Metal Back Electrode. Advanced Energy Materials 1, 68-71, doi:DOI 10.1002/ aenm.201000007 (2011).

21. Huang, J., Yin, Z. \& Zheng, Q. Applications of ZnO in organic and hybrid solar cells. Energ Environ Sci 4, 3861-3877 (2011).

22. Lilliedal, M. R., Medford, A. J., Madsen, M. V., Norrman, K. \& Krebs, F. C. The effect of post-processing treatments on inflection points in current-voltage curves of roll-to-roll processed polymer photovoltaics. Sol. Energy Mater. Sol. Cells 94, 2018-2031, doi:DOI 10.1016/j.solmat.2010.06.007 (2010).

23. Kim, J. et al. Light-soaking issue in polymer solar cells: Photoinduced energy level alignment at the sol-gel processed metal oxide and indium tin oxide interface. J Appl Phys 111, 114511 (2012).

24. Steim, R., Choulis, S. A., Schilinsky, P. \& Brabec, C. J. Interface modification for highly efficient organic photovoltaics. Appl Phys Lett 92, 093303, doi:10.1063/ 1.2885724 (2008).

25. Kim, C. S., Lee, S. S., Gomez, E. D., Kim, J. B. \& Loo, Y.-L. Transient photovoltaic behavior of air-stable, inverted organic solar cells with solution-processed electron transport layer. Appl Phys Lett 94, 113302 (2009).

26. Sista, S. et al. Highly Efficient Tandem Polymer Photovoltaic Cells. Adv Mater 22, 380-383, doi:10.1002/adma.200901624 (2010)

27. Gilot, J., Wienk, M. M. \& Janssen, R. A. J. Double and triple junction polymer solar cells processed from solution. Appl Phys Lett 90, 143512 (2007).

28. Cowan, S. R. et al. Chemically Controlled Reversible and Irreversible Extraction Barriers Via Stable Interface Modification of Zinc Oxide Electron Collection Layer in Polycarbazole-based Organic Solar Cells. Adv Funct Mater, DOI: 10.1002/adfm.201400158 (2014).

29. Trost, S. et al. Overcoming the "Light-Soaking" Issue in Inverted Organic Solar Cells by the Use of Al:ZnO Electron Extraction Layers. Adv Energy Mater 3, 1437-1444, doi:10.1002/aenm.201300402 (2013).

30. Hintz, H. et al. Photodegradation of P3HT-A Systematic Study of Environmental Factors. Chem Mater 23, 145-154, doi:10.1021/cm102373k (2010).

31. Manceau, M. et al. Effects of long-term UV-visible light irradiation in the absence of oxygen on P3HT and P3HT:PCBM blend. Sol Energ Mat Sol C 94, 1572-1577, doi:10.1016/j.solmat.2010.03.012 (2010).

32. Tromholt, T., Madsen, M. V., Carle, J. E., Helgesen, M. \& Krebs, F. C. Photochemical stability of conjugated polymers, electron acceptors and blends for polymer solar cells resolved in terms of film thickness and absorbance. J Mater Chem 22, 7592-7601 (2012).

33. Jørgensen, M. et al. Stability of Polymer Solar Cells. Adv Mater 24, 580-612, doi:10.1002/adma.201104187 (2012).

34. Alstrup, J., Jørgensen, M., Medford, A. J. \& Krebs, F. C. Ultra Fast and Parsimonious Materials Screening for Polymer Solar Cells Using Differentially Pumped Slot-Die Coating. Acs Appl Mater Inter 2, 2819-2827, doi:10.1021/ am100505e (2010).

35. Stubhan, T. et al. Overcoming interface losses in organic solar cells by applying low temperature, solution processed aluminum-doped zinc oxide electron extraction layers. Journal of Materials Chemistry A 1, 6004-6009, doi:10.1039/ c3ta10987a (2013).

36. Zilberberg, K., Meyer, J. \& Riedl, T. Solution processed metal-oxides for organic electronic devices. Journal of Materials Chemistry C 1, 4796-4815, doi:10.1039/ c3tc30930d (2013)

37. Mubeen, S. et al. An autonomous photosynthetic device in which all charge carriers derive from surface plasmons. Nat Nano 8, 247-251, doi:10.1038/ nnano.2013.18 (2013).

38. Chalabi, H. \& Brongersma, M. L. Plasmonics: Harvest season for hot electrons. Nat Nano 8, 229-230, doi:10.1038/nnano.2013.49 (2013).

39. Mubeen, S., Hernandez-Sosa, G., Moses, D., Lee, J. \& Moskovits, M. Plasmonic Photosensitization of a Wide Band Gap Semiconductor: Converting Plasmons to Charge Carriers. Nano Letters 11, 5548-5552, doi:10.1021/nl203457v (2011).
40. Hou, W. \& Cronin, S. B. A Review of Surface Plasmon Resonance-Enhanced Photocatalysis. Adv Funct Mater 23, 1612-1619, doi:10.1002/adfm.201202148 (2013).

41. Cushing, S. K. et al. Photocatalytic Activity Enhanced by Plasmonic Resonant Energy Transfer from Metal to Semiconductor. Journal of the American Chemical Society 134, 15033-15041, doi:10.1021/ja305603t (2012).

42. Li, J. et al. Ag@Cu2O Core-Shell Nanoparticles as Visible-Light Plasmonic Photocatalysts. ACS Catalysis 3, 47-51, doi:10.1021/cs300672f (2012).

43. Zhang, D. et al. Plasmonic Electrically Functionalized TiO2 for HighPerformance Organic Solar Cells. Adv Funct Mater 23, 4255-4261, doi:10.1002/ adfm.201203776 (2013).

44. Xie, F.-X. et al. Enhanced charge extraction in organic solar cells through electron accumulation effects induced by metal nanoparticles. Energy \& Environmental Science 6, 3372-3379, doi:10.1039/c3ee42440e (2013).

45. Bohren, C. F. \& Huffman, D. R. Absorption and Scattering of Light by Small Particles. (Wiley, 2008).

46. Mulvaney, P. Surface Plasmon Spectroscopy of Nanosized Metal Particles. Langmuir 12, 788-800, doi:10.1021/la9502711 (1996).

47. Whitney, A. V.et al. Localized Surface Plasmon Resonance Nanosensor: A High Resolution Distance-Dependence Study Using Atomic Layer Deposition. The Journal of Physical Chemistry B 109, 20522-20528, doi:10.1021/jp0540656 (2005).

48. Polywka, A., Vereshchaeva, A., Riedl, T. \& Görrn, P. Manipulating the Morphology of Silver Nanoparticles with Local Plasmon-Mediated Control. Particle \& Particle Systems Characterization 31, 342-346, doi:10.1002/ ppsc.201300175 (2014)

49. Leiter, F. et al. Oxygen vacancies in ZnO. Physica B: Condensed Matter 340-342, 201-204, doi:10.1016/j.physb.2003.09.031 (2003).

50. Lin, T. et al. Effective nonmetal incorporation in black titania with enhanced solar energy utilization. Energy \& Environmental Science, doi:10.1039/c3ee42708k (2014).

51. Skriver, H. L. \& Rosengaard, N. M. Surface energy and work function of elemental metals. Phys Rev B 46, 7157-7168 (1992).

52. Hong, J.-P. et al. Tuning of Ag work functions by self-assembled monolayers of aromatic thiols for an efficient hole injection for solution processed triisopropylsilylethynyl pentacene organic thin film transistors. Appl Phys Lett 92, 143311, doi:10.1063/1.2907691 (2008).

53. Dweydari, A. W. \& Mee, C. H. B. Oxygen adsorption on the (111) face of silver. physica status solidi (a) 17, 247-250, doi:10.1002/pssa.2210170128 (1973).

54. Onda, K., Li, B. \& Petek, H. Two-photon photoemission spectroscopy of $\mathrm{TiO} 2(110)$ surfaces modified by defects and $\mathrm{O} 2$ or $\mathrm{H} 2 \mathrm{O}$ adsorbates. Phys Rev B 70, 045415 (2004).

55. Marques, H. P., Canário, A. R., Moutinho, A. M. C. \& Teodoro, O. M. N. D. Work function changes in the Ag deposition on TiO2 (110). Vacuum 82, 1425-1427, doi:10.1016/j.vacuum.2008.03.016 (2008).

56. Zhou, Y. et al. Direct correlation between work function of indium-tin-oxide electrodes and solar cell performance influenced by ultraviolet irradiation and air exposure. Phys Chem Chem Phys 14, 12014-12021, doi:10.1039/c2cp42448g (2012).

57. Krebs, F. C., Tromholt, T. \& Jorgensen, M. Upscaling of polymer solar cell fabrication using full roll-to-roll processing. Nanoscale 2, 873-886, doi:10.1039/ b9nr00430k (2010).

58. Yeong, K. S., Maung, K. H. \& Thong, J. T. L. The effects of gas exposure and UV illumination on field emission from individual $\mathrm{ZnO}$ nanowires. Nanotechnology 18, 185608 (2007).

59. Sin Hui, W. et al. Enhanced Field Emission of TiO2 Nanowires With UV Illumination. Electron Device Letters, IEEE 35, 123-125, doi:10.1109/ led.2013.2287893 (2014).

60. Kind, H., Yan, H., Messer, B., Law, M. \& Yang, P. Nanowire Ultraviolet Photodetectors and Optical Switches. Adv Mater 14, 158-160 (2002).

61. Manjavacas, A., Liu, J. G., Kulkarni, V. \& Nordlander, P. Plasmon-Induced Hot Carriers in Metallic Nanoparticles. Acs Nano, doi:10.1021/nn502445f (2014).

62. Lim, D. C. et al. Towards fabrication of high-performing organic photovoltaics: new donor-polymer, atomic layer deposited thin buffer layer and plasmonic effects. Energy \& Environmental Science 5, 9803-9807, doi:10.1039/C2EE23359B (2012).

63. Kim, K.-D. et al. Surface Modification of a ZnO Electron-Collecting Layer Using Atomic Layer Deposition to Fabricate High-Performing Inverted Organic Photovoltaics. Acs Appl Mater Inter 5, 8718-8723, doi:10.1021/am402403x (2013).

64. Govorov, A. O., Zhang, H. \& Gun'ko, Y. K. Theory of Photoinjection of Hot Plasmonic Carriers from Metal Nanostructures into Semiconductors and Surface Molecules. The Journal of Physical Chemistry C 117, 16616-16631, doi:10.1021/ jp405430m (2013).

65. Sellers, M. C. K. \& Seebauer, E. G. Measurement method for carrier concentration in $\mathrm{TiO} 2$ via the Mott-Schottky approach. Thin Solid Films 519, 2103-2110, doi:10.1016/j.tsf.2010.10.071 (2011).

66. Zhang, G. Z. et al. Transparent capacitors based on nanolaminate $\mathrm{Al} 2 \mathrm{O} 3 / \mathrm{TiO} 2 /$ $\mathrm{Al} 2 \mathrm{O} 3$ with $\mathrm{H} 2 \mathrm{O}$ and $\mathrm{O} 3$ as oxidizers. Appl Phys Lett 104, 163503, doi:10.1063/ 1.4872470 (2014)

67. Kedem, O., Vaskevich, A. \& Rubinstein, I. Critical Issues in Localized Plasmon Sensing. The Journal of Physical Chemistry C 118, 8227-8244, doi:10.1021/ jp409954s (2014). 
68. Salvador, P. Hole diffusion length in $\mathrm{n}-\mathrm{TiO} 2$ single crystals and sintered electrodes: Photoelectrochemical determination and comparative analysis. Journal of Applied Physics 55, 2977-2985, doi:10.1063/1.333358 (1984).

69. Zhang, X., Liu, Y., Lee, S.-T., Yang, S. \& Kang, Z. Coupling surface plasmon resonance of gold nanoparticles with slow-photon-effect of $\mathrm{TiO} 2$ photonic crystals for synergistically enhanced photoelectrochemical water splitting. Energy \& Environmental Science 7, 1409-1419, doi:10.1039/C3EE43278E (2014).

70. Wilder, J. W. G., Venema, L. C., Rinzler, A. G., Smalley, R. E. \& Dekker, C. Electronic structure of atomically resolved carbon nanotubes. Nature 391, 59-62 (1998).

71. Pellegrino, O., Rei Vilar, M., Horowitz, G. \& Botelho do Rego, A. M. Oligothiophene films under electron irradiation: electron mobility and contact potentials. Materials Science and Engineering: C 22, 367-372, doi:10.1016/s09284931(02)00207-2 (2002).

72. Schierbaum, K. D., Kirner, U. K., Geiger, J. F. \& Göpel, W. Schottky-barrier and conductivity gas sensors based upon $\mathrm{Pd} / \mathrm{SnO} 2$ and $\mathrm{Pt} / \mathrm{TiO} 2$. Sensors and Actuators B: Chemical 4, 87-94, doi:10.1016/0925-4005(91)80181-I (1991).

73. Göpel, W., Rocker, G. \& Feierabend, R. Intrinsic defects of TiO2 (110): Interaction with chemisorbed O2, H2, CO, and CO2. Phys Rev B 28, 3427-3438 (1983).

\section{Acknowledgments}

We are grateful to S. Adamczyk from the Department of Macromolecular Chemistry (University of Wuppertal, Germany) for carrying out the AFM measurements. We thank Dr. Rogalla from RUBION (University of Bochum) for the RBS measurement. We acknowledge the German Federal Ministry for Education and Research (Grant No.
13N11777) and the Deutsche Forschungsgemeinschaft (DFG) (Grant: RI1551/4-1) for financial support. Honeywell Specialty Chemicals Seelze $\mathrm{GmbH}$ is acknowledged for the generous supply with P3HT. P.G. acknowledges funding by the Emmy-Noether-Programm of the DFG (Deutsche Forschungsgemeinschaft).

\section{Author contributions}

T.R. and P.G. conceived and designed the experiments. S.T., T.B., K.S., A.B., A.P. were performing the experimental work. R.H. provided the electron microscopy expertise. All authors discussed the results and were involved in the writing.

\section{Additional information}

Supplementary information accompanies this paper at http://www.nature.com/ scientificreports

Competing financial interests: The authors declare no competing financial interests. How to cite this article: Trost, S. et al. Plasmonically sensitized metal-oxide electron extraction layers for organic solar cells. Sci. Rep. 5, 7765; DOI:10.1038/srep07765 (2015)

This work is licensed under a Creative Commons Attribution-NonCommercialNoDerivs 4.0 International License. The images or other third party material in this article are included in the article's Creative Commons license, unless indicated otherwise in the credit line; if the material is not included under the Creative Commons license, users will need to obtain permission from the license holder in order to reproduce the material. To view a copy of this license, visit http:// creativecommons.org/licenses/by-nc-nd/4.0/ 